\title{
DIVERSIDADE: OS OUTROS DE “MIM”
}

José Leon Crochick (USP)*

\begin{abstract}
RESUMO
O objetivo deste ensaio é apresentar a expressão da diversidade como outras possibilidades de constituição do indivíduo, expressão essa possibilitada pela incorporação da cultura, o que indica a sua importância para a diferenciação individual. O meio para atingir tal objetivo é a análise de três novelas de Leon Tolstói: A morte de Ivã Ilitch, $O$ senhor e o servo e A felicidade conjugal, escritas no século XIX, e do filme de Michelangelo Antonioni Passageiro: profissão repórter, produzido no século XX. A análise dessas obras, permeadas por reflexões feitas por Adorno, Benjamin e Horkheimer, indica distinções na apresentação de outras possibilidades de constituição do eu na modernidade. Nas novelas de Tolstói, ressalta-se a alternativa de vida calcada na bondade, na serenidade, na solidariedade. No filme de Antonioni, destaca-se a impossibilidade de ser outro; a ideia de que tudo deva ser alterado para que tudo permaneça como está é visível nesse filme, contrapondo-se à percepção concreta da mudança presente nas novelas analisadas.
\end{abstract}

Palavras-chave: Diversidade. Modernidade. Cultura.

\begin{abstract}
DIVERSITY: THE OTHERS OF “ME”

The objective of this essay is to present the expression of diversity as other possibilities of constitution of the individual, an expression made possible by the incorporation of culture; which indicates the importance of this for individual differentiation. The means to achieve this goal is the analysis of three novels by Leon Tolstoy: "The death of Ivan Ilitch", "The Lord and the servant", and "Family happiness", written in the nineteenth century, and Michelangelo Antonioni's film "The Passenger", produced in the twentieth century. The analysis of these works, permeated by reflections made by Adorno, Benjamin and Horkheimer, indicates distinctions in the presentation of other possibilities of constitution of the self in modernity; in the novels of Tolstoy, the alternative of life based on kindness, serenity and solidarity stands out; in Antonioni's film, the impossibility of being another is outstanding; the idea that everything is altered so that everything remains as it is visible in this film, in opposition to the concrete perception of the change present in the analyzed novels.
\end{abstract}

Keywords: Diversity. Modernity. Culture.

\section{RESUMEN}

\section{DIVERSIDAD: LOS OTROS DE “YO”}

El objetivo de este ensayo es presentar la expresión de la diversidad como otras posibilidades de constitución del individuo, expresión que posibilita la incorporación

* Professor Titular do Instituto de Psicologia da Universidade de São Paulo (USP). Bolsista Produtividade em Pesquisa pelo CNPq. E-mail: jlchna@usp.br 
de la cultura; lo que indica su importancia para la diferenciación individual. El medio para alcanzar tal objetivo es el análisis de tres novelas de León Tolstói: "La muerte de Iván Ilitch", "El señor y el siervo" y "La felicidad conyugal", escritos en el siglo XIX, y de la película de Michelangelo Antonioni "El reportero", producido en el siglo XX. El análisis de estas obras, impregnadas por reflexiones hechas por Adorno, Benjamín y Horkheimer, indica distinciones en la presentación de otras posibilidades de constitución del yo en la modernidad; en las novelas de Tolstói, se resalta la alternativa de vida calcada en la bondad, en la serenidad, en la solidaridad; en la película de Antonioni, se destaca la imposibilidad de ser otro; la idea de que todo sea cambiado para que todo permanezca como está, es visible en esta película, contraponiéndose a la percepción concreta del cambio presente en las novelas analizadas.

Palabras clave: Diversidad. Modernidad. Cultura.

\section{Introdução}

A acessibilidade ao acervo de nossa cultura é fundamental para que todos os indivíduos, com ou sem deficiências, possam se diferençar, expressar suas sensações, medos, expectativas, pensamentos. Quanto mais a cultura for incorporada, mais as pessoas podem encontrar referências culturais, em suas diferentes linguagens, para que cada um possa expressar suas experiências, que de particulares possam tornar-se comunicáveis, e assim serem universais.

Quanto mais se incorpora a cultura, mais a subjetividade se constitui e mais se torna objetiva, por poder ser transmissível aos outros: a cultura dá voz à natureza e possibilita a humanidade, ainda não realizada, mas passível de o ser a partir das identificações com as experiências que todos vivem e podem ser transmitidas, objetivadas pelos meios que dispõem. A transmissibilidade não deve ser redutível à comunicação; o substancial é a experiência comunicada, que se não se separa da forma da comunicação, não pode amoldar-se a ela, mas mostrar a sua insuficiência, pois nunca nenhum objeto poderá ser plenamente comunicado: a identidade entre sujeito e objeto se desenvolve historicamente pela experiência, assinalando mais a diferença entre ambos - a não identidade - do que a igualdade. Nesse sentido, o acesso à cultura e a sua incorporação permitem a diversidade que não pode deixar de ser universal, identificável como humano por todos: na diferença, buscar o que é comum a todos, mas que será desenvolvido somente pela singularidade, quando esta for possível.
A singularidade somente será possível quando os indivíduos não forem mais ameaçados e sua expressão, que dela não se separa, puder superar a solidão do individualista, do indivíduo que mantém a ilusão de que o que veio a ser lhe é próprio, quando não poderia ser o que é se não obtivesse um nome e pudesse nomear suas experiências para as transmitir a outros. A palavra, o conceito, podem liberar, assim como aprisionar. Aprisionam quando fixam para controlar o que nomeiam; libertam quando outras possibilidades dos objetos nomeados puderem ser visualizadas e se tornar reais.

A ameaça sobre todos nós é visível, ainda que, como argumenta Adorno (2004a), quem não se comporte como esperado não necessariamente, nos dias de hoje, irá para a prisão ou para o campo de concentração, mas se dirá a ele: "você não é mais um dos nossos"; e "não ser mais dos nossos" implica estar só frente a todos os perigos de destruição existentes, perigos esses que a civilização se propôs a enfrentar. Ser diverso pode implicar a ameaça tornar-se mais próxima, ainda que pese sobre todos. Certamente, houve avanço social no acolhimento social ampliado da diversidade; formas de ser e agir que outrora sequer podiam ser mencionadas, hoje se tornam presentes no cotidiano; hoje, mais do que discutir sobre o gênero, já há apoio legal em diversos países para a troca de sexo, tanto no que diz respeito à esfera do Direito, quanto na transformação de corpo operada pela Medicina. Ainda assim, não são poucos os países que, atualmente, condenam a homossexualidade; 
não são raras também as discussões de religiosos que condenam qualquer tipo de família que não seja a defendida pela Bíblia. Se não pode haver singularidades, pode haver particulares, partículas, que se associam em minorias, que se definem por elas, mas não são propriamente singulares.

Em sua análise do antissemitismo, Horkheimer e Adorno (1985, p. 158-159) argumentam que:

Eles [os judeus liberais] achavam que era o antissemitismo que vinha desfigurar a ordem, quando, na verdade, é a ordem que não pode viver sem a desfiguração dos homens. A perseguição dos judeus, como a perseguição em geral, não se pode separar de semelhante ordem. Sua essência, por mais que se esconda às vezes, é a violência que hoje se manifesta.

Poder-se-ia dizer que o dito pelos frankfurtianos se referia a uma sociedade que superou sua "essência" violenta, mas em texto da década de 1960 - "Educação após Auschwitz" - Adorno (1995) indica que as condições objetivas que geraram o fascismo não se alteraram, o que implica que não deixou de existir, ainda que possa se manifestar de outras formas. Ainda assim, poder-se-ia contrapor que a sociedade se tornou mais democrática. No entanto, nem as condições sociais e políticas se alteraram do período do nazismo até os dias de hoje, nem é possível deixar de observar a violência existente na segunda década do presente século. Se nossa sociedade é contraditória, certamente, há progresso, assim como a sua força contrária, e é essa que impede a plena individuação própria do que se nomeia singularidade; pode-se ser, no máximo, particular, parte de minorias, que ainda resistem à plena integração.

$\mathrm{O}$ individualismo que se opõe à formação do indivíduo como singular, por sua vez, é produto da negação da dependência dos outros para que cada qual possa se constituir. Conforme Freud (1975), o indivíduo se constitui a partir de múltiplas identificações com outros segundo sua percepção de como são, isto é, a identificação não é a reprodução pura e simples de quem é identificado, mas ocorre segundo a percepção que se tem desse, que por sua vez é mediado por desejos e fantasias. Importante também para a constituição de um eu, segundo o mesmo Freud (1986), é o contraste entre a fantasia e a realidade possibilitado pela experiência, o que indica que as identificações também são corrigidas pelas experiências. Ora, a ideia do mérito, da genialidade, de que se é o mesmo desde o nascimento até a morte, se contrapõe à compreensão que a diferença entre os indivíduos não é gigantesca e que esses são frutos da convivência e das experiências que são possibilitadas. $\mathrm{O}$ que se torna propício a fortalecer o que foi enfatizado antes: a subjetividade e a objetivação individual, possível pela incorporação da cultura.

Nessa sociedade, dessa forma, não há a possibilidade de se ser diverso, mas é possível se perceber essa impossibilidade e agir para que seja superada, em uma sociedade que estende a ameaça anteriormente presente na natureza para si mesma. Os indivíduos diferençados existentes como particulares, ainda são caricaturas da diversidade, aparência de um desejo universal que os artistas sempre expressam: o de sermos muitos, ao sermos cada um. Se a neurose, descrita por Freud (1986), poderia ser um protesto contra uma cultura que não cumpriu suas promessas, que não compensou os sacrifícios exigidos pelo adiamento da satisfação dos desejos; após a sua assimilação social, passou a ser, conforme Adorno (1992), também reprimida, indicação que somos mais reprimidos, e não menos, do que nos tempos vienenses, analisados por Freud.

Para ilustrar a busca da diversidade possível, assim como os obstáculos existentes à verdadeira diversidade, presente também nas metamorfoses ocorridas ao longo da vida individual e que podem mostrar a importância da incorporação da cultura, serão expostas, neste ensaio, obras que permitem refletir essas transformações. A diversidade será pensada a partir de obras artísticas: três novelas de Leon Tolstói e um filme de Michelangelo Antonioni. Tais obras foram produtos de outras épocas e lugares e, assim, não podem ser responsáveis pelo que este autor irá desenvolver; elas serão analisadas em conformidade com o interesse deste texto: pensar a diversidade; em hipótese alguma se tem a pretensão de reduzir sua imensa riqueza a esse propósito. Antes de apresentá-las, cabe, no entanto, algumas palavras a mais, em relação às já enunciadas antes, sobre a formação do eu a partir da diferenciação dos outros (Outro). 


\section{O Eu e os outros (Outro)}

Em alguns trabalhos de Freud (1975, 1993), o eu se forma por meio de identificações com pessoas importantes para nossa sobrevivência, para nosso afeto e para nossos possíveis projetos. $\mathrm{O}$ conceito de identificação pode ser aproximado do conceito de mimese - reapresentação do outro, conforme nós o percebemos por meio de nossas fantasias e experiências com ele. Parte de nossa psique se transforma, por meio dessa reapresentação, como uma reconfiguração de si mesmo, e parte dessa transformação, por vezes, se transforma, também por identificação, em consciência moral. Assim, o eu se constitui por meio do outro; não tal como é (se existir essa definição precisa), mas, como assinalado, mediado por fantasias e experiências.

Para a constituição do eu, só as identificações não bastam; as experiências que confrontam os desejos e a possibilidade de sua realização e indicam se a realidade pode ser transformada para essa realização também contam para confrontar e modificar o que se estruturou como um eu: as identificações constituem um eu, mas para sua constituição, essas identificações precisam ser superadas. Para a constituição de um eu, assim, é necessário primeiro a aproximação do outro, para depois haver o afastamento, para por fim haver um reconhecimento da distinção e da origem com a qual se assemelhou; por isso, muitas vezes, o afastamento é necessário para que possa haver reaproximação.

$O$ diverso envolve a semelhança e a diferença com os que há identificação. Nesta perspectiva, não cabe pensar o diverso sem nenhuma referência, sem nenhuma relação com outros que lhe proporcionam a diferença; há diversidade, porque há unidade: de início como fusão eu-outro; depois como relação entre diferentes. $O$ próprio pensamento só pode não ser reprodutivo quando se distancia da realidade para melhor conhecê-la, para depois se reconhecer nela, como seu produto. Esse movimento de fusãodiferenciação-reconhecimento naqueles dos quais se afastou é fundamental para a diferenciação do outro, para que seja diverso desse outro.

$\mathrm{Se}$, como ressaltado, a identificação se aproxima da mimese e essa é própria à arte, pode-se dizer que a constituição individual se deve a um processo artístico. Se em Marx (1978), pela transformação da natureza, nos transformamos, no quanto nos percebemos em nossa obra, em Freud $(1975,1986,1993)$ esse processo artístico se dá na relação com os outros, mediado pelas necessidades de conservação e de amor, ambos associados pela possibilidade de vida. É na arte também que se pode buscar a identificação como diversidade. Por que pelas experiências e individualidades expressadas é possível a todos pensarem sua própria vida a partir de alguém que é semelhante e diferente ao mesmo tempo. Na novela de Tolstói (1959b) A morte de Ivã Ilitch, a ser comentada a seguir, no fim da vida, a diversidade reaparece como ressurgimento do que não foi, e nesse sentido, identificação com outro que não se desenvolveu.

\section{A Morte de Ivã Ilitch}

Essa novela de Leon Tolstói (1959b), publicada em 1886, narra a vida de um homem que seguiu a vida a partir do que pareceu ser sensato, segundo podia presumir do que os outros diziam e praticavam. Centrado em seus interesses, não era um homem incomum. Bem-sucedido profissionalmente e financeiramente, de início com bom relacionamento com sua esposa e filhos, quando adoece, de certo modo, antecede o personagem de Kafka (1998), de $A$ Metamorfose, que se transforma num imenso inseto repugnante. Sua família quase não se volta mais a ele, a não ser para preocupações formais, próprias dos costumes, pois os costumes determinam que se deve cuidar bem dos familiares. Seus colegas de trabalho passam a se preocupar com quem vai assumir seu importante posto de trabalho. A hipocrisia das pessoas com as quais convive em casa e no trabalho mostra sua verdadeira face: só era prezado pelo que podia sustentar; quando adoece, pode ser deixado de lado.

Com exceção de seu filho menor, que se compadece do pai, e de um criado, que o faz se sentir ainda humano, não há mais ninguém que preze por sua vida, ainda que tentem manter as aparências em contrário. Em seus últimos dias, passa a se perguntar no que errou nas decisões que tomou em sua vida. Percebe que uma outra vida seria possível e mais propícia ao que é humano, percepção vinda do afeto ainda restante do filho e do criado. 
Dessa novela ressalta-se uma vida verdadeiramente humana, calcada no afeto, no cuidado, que não são subjacentes à vida que foi levado a escolher seguindo os critérios mundanos: ter uma boa profissão, estar bem empregado, constituir uma boa família, desfrutar de noites de jogos de cartas com os colegas. E é por meio daquele que ainda tem pouca experiência - seu filho -, isto é, que não se corrompeu quanto a uma possível vida digna de ser vivida, e por meio do criado - que entendia e tentava atenuar a sua dor -, que pode visualizar o que perdeu, reconfortando-se por ter achado a resposta à sua pergunta sobre o que havia errado.

A diversidade, nessa novela, surge como outra possibilidade de vida presente ainda nos que não sucumbiram aos valores burgueses. Esses últimos os valores burgueses - se referem a uma aparência de vida feliz, a uma identificação com pessoas que trazem valores próprios à objetificação da vida. De todo modo, é um diverso como distinto também de si mesmo, uma vez que esse, como ressaltado anteriormente, é produto de outros. Sua diversidade aparece com referência a algo que se constituiu e que ao fim da vida o frustra. $\mathrm{O}$ criado, diretamente contratado por ele, consegue superar o valor de troca do contrato e se revelar humano; os que têm outros "contratos" - o do casamento, o de colegas de ofício e de carteado - submetem-se diretamente a ele $-\mathrm{o}$ valor de troca.

A ideologia que se refere à grandeza da pobreza, da humildade, da solidariedade, expressas no criado e no filho, como ideologia própria à época do liberalismo, segundo Horkheimer e Adorno (1973), é falsa e verdadeira. Verdadeira como desejo universal: os indivíduos deveriam ser solidários, humanos, mas não podem sê-lo em uma sociedade que não lhes dá as bases para isso. Conforme pode-se depreender de um texto de Adorno (2004b), só há uma formação: a burguesa, que traz contradições que devem ser superadas, mas mesmo os sentimentos considerados mais elevados existem não em razão de uma suposta naturalidade, e sim do cultivo de civilização que tenta superar sua destruição, presente na barbárie. De todo modo, o outro eu não desenvolvido por Ivã Ilitch não deixa de ser um apelo à superação dos limites burgueses. É certo que no texto acima referido de Adorno (2004b), o autor defende que quem não foi exposto à pseudocultura pode manter em sua rudeza uma crítica a que os outros já sucumbiram, e que o saber prático do cotidiano que auxilia na manutenção da vida é importante, mas isso não os torna superiores aos pseudocultos. Nesse sentido, a crítica que direcionou a Marx e a Engels é a de terem desprezado como mera ideologia a esfera da produção cultural. A cultura, para pensar a sociedade, deveria afastar-se da realidade imediata para depois retornar a ela. Disso depreende-se que quer a prisão à realidade existente, de que Ivã Ilitch, ao fim da vida, liberta-se, quer o mero afastamento, são formas de falsas vidas. $\mathrm{O}$ outro eu experimentado por meio dos outros - criado e filho - ao fim da vida reclama por uma outra sociedade, pois esta impede a todos - senhores e servos - de viverem uma vida não mediada pelo valor de troca, valor esse que se sobrepõe a todos os demais, como o de solidariedade, por exemplo. Não é que não haja momentos de solidariedade, de compaixão, enfim, de bondade; há em demasia, e por todo lugar, mas são confortos diante de uma sociedade que frutifica em sua esterilidade, ou seja, não frutifica. Tal contradição é exposta por Horkheimer e Adorno (1985, p. 84-85), ao explicitarem o desespero de Kant:

Sua tentativa [de Kant] de derivar de uma lei da razão o dever do respeito mútuo - ainda que empreendida de maneira mais prudente do que toda a filosofia ocidental - não encontra nenhum apoio na crítica. É a tentativa usual do pensamento burguês de dar à consideração, sem a qual a civilização não pode existir, uma fundamentação diversa do interesse material e da força, sublime e paradoxal como nenhuma outra tentativa anterior, e efêmera como todas elas. $\mathrm{O}$ burguês que deixasse escapar um lucro pelo motivo kantiano do respeito à mera forma da lei não seria esclarecido, mas supersticioso - um tolo. A raiz do otimismo kantiano, segundo o qual o agir moral é racional mesmo quando a infâmia tem boas perspectivas, é o horror que inspira a regressão à barbárie.

$\mathrm{Na}$ defesa do imperativo categórico se encontra a tentativa desesperada de evitar que a desumanidade prospere com base no único valor que reconhece: o da anulação do uso humano em favor do que atribui equivalência às mercadorias. Na defesa da compaixão, Horkheimer e Adorno (1985, p. 98) indicam seus limites: 
De fato, a compaixão tem um aspecto que não se coaduna com a justiça, com a qual, porém, Nietzche a confunde. Ela confirma a regra da desumanidade através da exceção que ela pratica. Ao reservar aos azares do amor ao próximo a tarefa de superar a injustiça, a compaixão acata a lei da alienação universal, que ela queria abrandar, como algo inalterável.

O criado de Ivã Ilitch talvez não fosse compassivo, mas compreensivo: conseguia entender e se identificar com o sofrimento de seu senhor. Para além das diferenças de classes sociais, conseguia perceber o universal da humanidade: não o sistema que nos habita, mas os necessários habitantes da vida. Se isso é procedente, Tolstói não recai, nessa novela, na ideologia burguesa, mas faz sua crítica. É a identificação e não a compaixão que aproxima senhor e criado; mas identificação entre pessoas e não com ideais, a não ser que esses procedam desses indivíduos na composição do que é universal. Não se trata, portanto, de identificação cega com algum ideal coletivo, tal como ocorre nos movimentos fascistas ou naqueles que os indivíduos não puderam desenvolver suficientemente a consciência moral - que segundo Freud (1993) é fundamental para se contrapor à violência -, mas daquela que permita a preservação do que é humano.

Alguém poderia opor-se a essa interpretação alegando que a proximidade de Tolstói com a religião o levaria a defender algo próprio ao Idealismo e ao Cristianismo, mas ele parecia pensar para além das ideologias, e, nessa novela, fez a crítica à hipocrisia. Mais do que uma diferenciação de um outro eu, o autor, nesse texto, revela um verdadeiro eu que antes se ocultava por um falso e superficial, posto que muito próximo à obediência às normas e costumes.

Essa diversidade, todavia, pode ser pensada também em relação ao outro.

\section{O senhor e o servo}

Na novela de Tolstói (1998) O senhor e o servo, publicada em 1894, a relação entre ambos é central, ainda que na obra anterior, como descrito, não possa ser considerada periférica. O senhor é um orgulhoso homem que, por seu trabalho e astúcia, conseguiu sua fortuna e que por essas mesmas habilidades despreza seu servo. O servo, por sua vez, quando bebe, maltrata a família, e quando está sóbrio, é bastante afetuoso e cioso de suas obrigações na vida no cuidado dos outros; o cuidado do servo com os outros novamente reaparece, tal como já esteve presente nos cuidados do criado de Ivã Ilitch.

O senhor é prezado por sua mulher, que também se preocupa com ele, mas ele a despreza como pouco inteligente. $\mathrm{O}$ servo, afora os momentos em que se torna outro pela bebida, é um homem cuidador também da família. O julgamento do senhor, quer do servo, quer de sua esposa, parece aproximá-los da noção de natureza que julga pretender dominar, para que a própria astúcia e trabalho possam se desenvolver. Se isso é correto, aproxima-se do ideal burguês de dominação da natureza exposto por Horkheimer e Adorno (1985). Percebe nesses outros algo que já superou e que não consegue ver mais em si mesmo e, não obstante, como demonstrou a Psicanálise, ainda se preserva em outra área não consciente do sistema psíquico (FREUD, 1986).

O senhor quer comprar terras, e numa noite de intensa nevada no interior da Rússia czarista, resolve levar parte do pagamento para poder fechar o negócio, antes que outros o façam. A esposa insiste para que não vá sozinho, e o senhor concede que o servo o acompanhe. A nevada apaga os rastros do caminho e eles se perdem; ao anoitecer, conseguem localizar um vilarejo, no qual são bem recebidos. Como defesa contra o poder da natureza, o anfitrião e o servo entendem que é necessário se resguardarem, aguardando até o próximo dia para seguirem viagem; o senhor, no entanto, tem pressa: não pode perder o negócio, orgulha-se de ser arriscado, para justificar sua fortuna.

Perdem-se novamente e resolvem parar e passar a noite em meio à nevada, agasalhando-se como podiam num frio intenso. $\mathrm{O}$ senhor tentava se aquecer lembrando como acumulou a sua fortuna devido ao seu empenho e inteligência, qualidades que, pensava, diferiam-no do servo. O senhor, não aguentando esperar o tempo passar, resolve pegar o cavalo e seguir viagem, deixando o servo à sua própria sorte; mas, sem sinalização, volta ao lugar onde seu servo estava: nem o tempo nem o espaço mudam para que o senhor possa mudar; o pretenso senhorio da história e da geografia volta-se contra o senhor. Se o tempo e o espaço constituem 
o indivíduo, o controle sobre eles dificulta a vida prosseguir seu rumo, tal como mostra a análise de Horkheimer e Adorno (1985) do personagem Ulisses, da Odisseia, escrita por Homero: o herói, para se conservar, deve se sacrificar.

O servo já sem sentidos, e ainda não morto, jazia no lugar que havia se resguardado; o senhor, o vendo, deitou-se sobre ele para lhe transmitir calor com a finalidade de mantê-lo vivo. Na manhã seguinte, acharam o senhor e o cavalo mortos, e o servo em condições precárias, mas vivo; após tratamento, perdeu alguns dedos e voltou a cuidar e a ser cuidado por sua família.

O diverso, nessa novela, também aparece na hora da morte, e em relação com o servo; e nesse caso, realiza sua própria vida cedendo-a ao outro. A perda do caminho o fez se reencontrar, e ele pôde ser outro, contrário do que era. O que servia para encorajá-lo, quando aguentava o frio na floresta o pensamento de como conseguira sua fortuna -, cedeu lugar à solidariedade com aquele que julgava inferior.

Nas duas novelas, as condições sociais que estabelecem as condições de vida dos senhores e dos servos, ou, se preferirmos, do patrão e do empregado, indicam a possibilidade da diversidade no contraponto que estabeleceram: o diverso é o outro com o qual se relacionam e indica o sentido contrário. Interessante ressaltar que, nessa segunda novela, o senhor, como mencionado antes, se perde para se reencontrar, ou encontrar o outro de si, que com ele convivia e que o servia. Se o senhor burguês, ou mesmo o feudal, dá a ordem, a experiência da vida está em quem lhe serve; não deve ser casual a remissão não explicitada a Hegel (1988), em sua análise da relação entre o senhor e o servo.

A diversidade, nessa novela, assim como na outra, ou melhor, a transformação que o senhor sofre, nas duas novelas, não é simplesmente para um outro, mas, ao que parece, para um outro não só melhor, como redentor do anterior. Talvez, ao contrário do afirmado anteriormente, a religiosidade do autor leve à redenção de seus personagens, de forma similar à que ocorre com os personagens de Dostoievski (2001) em sua obra Crime e Castigo; para nosso propósito, no entanto, o motivo religioso não é suficiente para a identificação do que é humano.
O jovem Proust (2003) dá forma distinta a alguns de seus personagens ao fim da vida: a um - o protagonista de A morte de Baldassare Silvande, Visconde de Sylvanie -, lembranças agradáveis de sua vida vieram se juntar às passagens que admirava; a outro - personagem de O fim do ciúme -, a paixão em relação à sua amada se desvanece. São essas as palavras do jovem autor nesse último conto:

Em lágrimas, aos pés do leito, ela murmurava as mais belas palavras de outrora: 'Meu país, meu irmão'. Mas ele, não tendo nem o desejo e nem a força de desenganá-la, sorria e pensava que seu 'país' não estava mais nela, mas no céu e sobre toda a terra. Ele repetiu em seu coração: 'Meu irmão', e se ele a olhasse mais do que aos outros, era somente por piedade, pela torrente de lágrimas que ele via correr dos olhos dela; seus próprios olhos, que em breve se cerrariam, já não choravam mais. Mas ele não a amava nem mais e nem de uma forma diferente que ao médico, às velhas parentas, aos empregados. Era aquele o fim do seu ciúme. (PROUST, 2003, p. 230, grifo do autor).

Nesses dois contos de Proust, a proximidade da morte não transforma, recua, revê; não diferencia, mistura-se com tudo e com todos, talvez se reencontrando com um amor universal. Não há diversidade, a não ser a que fica na lembrança. A compaixão é para os que permanecem vivos e continuam a sofrer por aquele que finda a identificação que diferencia. Um amor distinto da posse do ciúme se apresenta junto à morte; não há o arrependimento do que não foi, revela-se o desvanecimento da paixão que, necessariamente, se relaciona com um objeto bem delineado, mas que não deveria deixar de ser posse. A libertação, nesses contos, ocorre pelo desligamento e não pelo (re)ligamento a um outro eu. O autor de Em busca do tempo perdido viveu menos tempo do que o escritor russo, e em país distinto quanto aos progressos sociais e culturais; ainda assim, se esse último lamentava pela vida que não foi, o primeiro buscava, no que pode ser recordado, o sentido de uma vida que se perdia no passado. A recordação não é o fato revivido, mas a lembrança ressuscitada, que combina a vida com a imaginação do que talvez tenha acontecido, da mesma forma que a paixão idealiza seu objeto. Sem essa idealização, a experiência não é necessária 
para que se torne produto do sujeito que imagina; essa experiência é fundamental para diferençar, segundo Freud (1986), fantasia da realidade, sem necessariamente eliminar o encantamento da primeira. $\mathrm{O}$ desencantamento que a experiência pode trazer não deve desencantar o próprio indivíduo que experimenta, que atribui sentido à sua vida $\mathrm{e}$ à dos demais; sem essa imaginação, presente na idealização, não há humanidade.

A humanidade que Baudelaire (1998) dotou às flores do mal, produtos da nova vida citadina - os bêbados, os ladrões, as prostitutas -, possibilitou que fossem críticas do esvaziamento da vida propícia à circulação das mercadorias pelas largas avenidas da nova Paris do século XIX. O ladrão abre suavemente a porta da casa que assalta, com mão de veludo; as amantes possibilitam o consolo diante de uma vida fria e a promessa de uma vida amorosa para além da mercadoria, em que a prostituta se tornou. Volúpia e melancolia, para o antecessor de Proust, revelavam um objeto perdido e o desespero de o reencontrar. A melancolia, em Baudelaire, assim como a neurose para Freud, é crítica às luzes que escondem o que foi perdido nas sombras. Não se trata, como parece ocorrer com os personagens do escritor russo, da negação determinada, tal como Hegel a concebe, que não pode ser pensada sem uma teleologia, mas de algo que não foi possível ainda existir, mas insiste em se manter possível. Tal como a crítica à ideologia presente no primeiro texto, brevemente analisado, trata-se de crítica à ideologia, mas sem que o "vir a ser" esteja claramente delineado, a não ser como "promessa de felicidade" em um mundo livre.

Se nas duas novelas brevemente comentadas de Tolstói o diverso está ao fim do caminho, na próxima novela ele aparece no próprio caminhar.

\section{A felicidade conjugal}

Essa novela, escrita antes das duas outras, em 1859 , traz como narrador, a personagem principal - uma jovem que recorda sua vida a partir de 17 anos, quando perde sua mãe. Interessante marcar que Leon Tolstói (1959a) se identifica com uma jovem mulher narradora, o que já indica diversidade.

Quando seu futuro marido e amigo do pai, também já falecido, aparece para dar condolências, lembra-se que sua mãe havia lhe dito que gostaria que um homem assim a desposasse. A presença do pai/marido revela continuidade, mas também alteração. Na época, ele estava com 34 anos, considerado já maduro.

O pretendente fica em dúvida se deve ou não se casar com a moça tão jovem pela qual se apaixonara, o que acaba ocorrendo. Moram no campo, com a mãe do moço, e ambas as famílias são ricas. Nos primeiros tempos são muito felizes, mas o tédio começa a perturbar a moça, e começam a viajar para as grandes cidades.

Ela, jovem e bonita, conquista a elite dessas cidades e é convidada para diversas festas, nas quais é o centro das atenções; seu marido quer regressar para sua casa no campo, mas ela, mesmo após ter dois filhos, continua a querer ir a festas, só existentes em grandes centros.

Em uma viagem ao exterior, outra moça, mais jovem do que ela, passa a tomar seu lugar, ainda que ela também continue a ser prestigiada. Um dos frequentadores dessas festas, às quais o marido deixa de comparecer, lhe faz a corte, e em outra situação, quando se vê a sós com ela, tenta beijá-la; ela consegue se desvencilhar, e se sente envergonhada frente a uma amiga que viu o incidente, e se sente culpada frente ao marido.

Ela e o marido voltam à casa de campo, e o intenso amor que tinham é substituído por uma calmaria. Ela pergunta a ele por que deixou frequentar esses bailes, uma vez que ele não os aprovava; ele responde que já havia vivido a própria vida quando a conhecera, mas ela não, e que não queria impedir que a vivesse. Terminam com uma outra forma de amor: a dos cuidados recíprocos.

Nessa novela, a diversidade aparece pelas experiências que a moça passa a ter, nas quais vai se tornando outra que não conhecia, para retornar ao que era, mas agora madura. O diverso no qual ela se tornara, desta feita, não é o servo, mas o que guarda a experiência, o conhecimento da vida: o marido. Ela própria teve que sair do que era para voltar a si mesma, mas agora como senhora. $\mathrm{O}$ destino pretendido pela mãe "sai do caminho", perde-se como o senhor da novela anterior, e como ele volta à origem, mas transformado.

Se o cuidado entre os cônjuges ao fim da novela é recíproco, ele é notável no marido desde o início: 
a generosidade, a compreensão, a identificação com a qual entende, sem deixar de se perturbar, que a moça precisa ter algumas experiências que não sejam junto a ele. Como nas outras duas novelas, ocorre o reencontro com uma vida que não foi possível se viver antes. Nos três casos, parece que o desvio foi necessário para que o renascimento fosse possível. Ao contrário dos contos citados de Proust, o fim não é a despedida, ou o retorno à origem, mas a possibilidade da ciência de um outro porvir.

Novamente, o contraste com a obra de Proust pode ser interessante para a compreensão do objeto deste ensaio - a distinção com a qual a diversidade é percebida ao longo do tempo e expressa pela literatura. O amor de Swann por Odette (PROUST, 1992) retrata o enlouquecimento que a paixão traz, já presente no conto $O$ fim do ciúme. O casamento, contudo, abrandou a paixão, e cada qual retorna à busca de sua vida anterior. Ao contrário, na novela de Tolstói, há o fortalecimento dos elos amorosos sob outra forma. Freud (1993) define o amor burguês como a síntese entre o amor puramente sensual com o amor inibido em sua finalidade, esse último responsável pelo carinho, pela preservação, pelo cuidado com o ser amado, e apresenta como patológica a cisão entre as duas tendências, o que leva o homem a poder ter atração sexual somente pela prostituta e amor somente para a esposa. Se aplicado à novela de Tolstói, a experiência conduz da paixão ao amor. No caso dos personagens de Proust, não há mais lugar para o amor, somente para a paixão; a preservação do ser amado se perdeu, e não só o tempo.

Nas três novelas, o cuidado que aproxima torna-se modelo de identificação para a mudança, para o diverso: nas duas primeiras, o servo; na última, o marido. Nas duas primeiras, as relações afetivas entre pessoas se sobrepõem, ao fim, às relações pessoais frias, mediadas pela posse de bens materiais; na última, o cuidado perene no caminho até o fim substitui paixões regidas pela vaidade.

Interessante notar que se o poeta Baudelaire exaltava a volúpia e a melancolia em conjunto, só aparentemente se contrapôs a Tolstói. Pela volúpia se busca um objeto perdido; se este é ou não reencontrado pelos personagens de Tolstói nas novelas aqui referidas, é outra questão, pois se referem à negação do vivido e não a algo que não pode se expressar. Essa outra questão retorna no filme de Antonioni Passageiro: profissão repórter (PASSAGEIRO..., 1990).

\section{Passageiro: profissão repórter}

Nesse filme de Antonioni, de 1975, o personagem principal é um famoso jornalista de televisão, bem-sucedido, casado, que faz uma reportagem na África sobre o tráfico de armas em uma região em conflito. Faz contato, no hotel, com um homem, que virá a morrer, que é traficante de armas. Como ambos têm algumas semelhanças físicas, o repórter toma o lugar do traficante e faz com que seja considerado morto. Passa a viver a nova vida, por meio de uma agenda que encontra desse traficante. Daí viaja para diversos lugares até chegar a Barcelona.

De início, é interessante notar que de jornalista, que trafica a palavra, passa a comerciar armas; se altera da expressão da vida para a expressão da morte; o contrário, também nesse caso, apresenta-se além da profissão: o mercador de armas, pelo que é indicado, é homossexual.

A mulher do repórter trasvestido de traficante recebe o passaporte de seu marido com a foto trocada; depreende então que ele não morreu e pede para um colega do jornalista procurá-lo. Começa a perseguição. $O$ traficante simulado conhece uma moça - arquiteta - em visita a um prédio construído por Gaudí e viajam rumo ao sul da Espanha para cumprir a agenda do traficante como tentativa de fuga, uma vez que viu seu ex-colega em Barcelona. Mais uma vez, o novo papel é assumido para a fuga; esse novo papel não é para ser vivido, mas para fugir, esconder-se da vida passada, eliminar os rastros do passado. No prédio de Gaudí, a arquiteta diz que essa construção é propícia para se esconder: tal como Benjamin (1989) argumenta, na multidão própria à modernidade, o assassino se esconde. $O$ prédio em questão parece ser uma multidão de lugares para visitação; como próprio ao turismo, não é para fixar residência permanente. No conto de Poe O homem na multidão, analisado por Benjamin (1989), no século XIX, a cidade era propícia para se esconder; no século seguinte, ao que parece, o esconderijo se encontra não mais somente na multidão das ruas, mas também nos prédios. 
Ao final, quando é procurado também pela polícia, se separa da arquiteta e vai para um hotel, no qual é assassinado. Na sequência, a polícia, a esposa e a arquiteta estão no quarto para reconhecê-lo: a esposa disse que não o conhece; a arquiteta confirma o reconhecimento: o outro foi reconhecidamente morto, o novo também a partir de agora: no limite a diversidade ou a liberdade de um eu anterior não é possível. Em uma das cenas em que está indo com a arquiteta para o sul da Espanha, a moça lhe pergunta do que está fugindo, ao que ela responde: de tudo que ficou para trás; em sua morte, escapou também do futuro.

Se o início da história é na África, o final é na fronteira da Espanha com Marrocos; no deserto em que é assassinado não há lugar para se esconder; na modernidade, só se pode ser reconhecido como outro, na morte, o que também se apresentou, ainda que de forma distinta nas duas primeiras novelas apresentadas de Tolstói e nos contos citados de Proust. Se nessas novelas e contos o reencontro com possibilidades perdidas é possível, no século seguinte, não mais. Nas novelas de Tolstói, um eu que não foi possível toma corpo, mesmo ao final da vida; nos contos de Proust, as paixões ficam no passado, destituídas de encanto frente à morte; no filme de Antonioni, o diverso não é a mera negação do falso em virtude do verdadeiro, ou o desvanecimento das paixões, mas a fuga do passado em virtude da possibilidade de uma nova vida.

Tal como Ivã Ilitch, o passageiro tinha uma vida bem-sucedida conforme os padrões sociais. Mas se o primeiro teve de adoecer para pensar na possibilidade de ser outro, influenciado pela presença do criado e do filho, o último teve na morte do outro a possibilidade de uma nova vida, possibilidade não passível de se realizar, pois as novas técnicas descritas por Benjamin (1989) de buscar o assassino nas massas impedem que alguém tente ser diferente do que é.

Segundo Horkheimer e Adorno (1985, p. 101), a prisão a um eu é antiga, mas o gozo coletivo permitia, no passado, dar vazão à natureza primitiva, $o$ que deixa de ocorrer nos tempos modernos:

É só com o progresso da civilização e do esclarecimento que o eu fortalecido e a dominação consolidada transformam o festival em simples farsa. Os dominadores apresentam o gozo como algo racional, como tributo à natureza não inteiramente domada; ao mesmo tempo procuram torná-lo inócuo para seu uso e conservá-lo na cultura superior; e finalmente, na impossibilidade de eliminá-lo totalmente, tentam dosá-lo para os dominados. O gozo torna-se objeto de manipulação até desaparecer inteiramente nos divertimentos organizados.

Segundo esses autores, a luta pela autoconservação segue junto com a autodestruição, que não necessariamente significa a morte, mas a liberdade de um eu, que é possível no sonho:

Os homens só sentem a magia do gozo, quando o sonho, liberando-os da compulsão ao trabalho, da ligação do indivíduo a uma determinada função social e finalmente a um eu, leva-os a um passado pré-histórico sem dominação e sem disciplina. É a nostalgia dos indivíduos presos na civilização, o 'desespero objetivo' daqueles que tiveram que se tornar em elementos da ordem social, que alimenta o amor pelos deuses e demônios: era para esses, enquanto natureza transfigurada, que eles se voltavam na adoração. $O$ pensamento tem origem no processo de liberação dessa natureza terrível, que acabou por ser inteiramente dominada. O gozo é por assim dizer sua vingança. Nele os homens se livram do pensamento, escapam à civilização. (HORKHEIMER E ADORNO, 1985, p. 100-101, grifo do autor).

Ao que parece, nenhum dos personagens analisados neste ensaio busca a liberação do pensamento, escapar da civilização, mas, como no sonho, podem estar tentando ficar livres da eterna repetição a que se obrigam e são obrigados todos que constituem um eu que nega outras possibilidades, e, mais do que isso, se formam ao negar essas outras possibilidades. A natureza reprimida decerto possui essas possibilidades, que não necessariamente devem se voltar contra a vida civilizada, mas quando são negadas, pela domesticação cada vez mais intensa dos desejos humanos, associados à natureza e também à "voz" que a cultura dá a ela, pode transbordar em explosões ou no reconhecimento de que há alternativas.

A esposa do "passageiro" tinha discórdias do marido, julgando que esse concedia em demasia aos entrevistados, mesmo quando se tratavam de ditadores; não estava se relacionando bem com ele, já tinha um amante; apesar disso, da vida afetiva pretensamente resolvida, não aceitou a tentativa 
de seu marido ser outro: pode-se ter outros, e perseverar no si mesmo, mas não se pode ser outro. A traição que mantém o eu é esperada e compreensível, a mudança de identidade, não. Quando ele se adaptava às circunstâncias, adaptação necessária ao seu ofício, ou pelo menos à forma que lhe deu sucesso no exercício desse ofício, ela reclamava; quando transgrediu por completo o que era adaptativo, ela não pôde aceitar, sentiu-se traída. Por outro lado, a adaptação excessiva pode ser superada por sua extrema negação: antes, não era quem desejava ser - tinha de conceder em demasia a tiranos que lhe tiravam sua própria consciência; depois, não pôde ser quem flagrantemente colaborava com os tiranos pela venda de armas. Como mercador de notícias, matava a si mesmo; como mercador de armas, poderia contribuir para a morte aleatória de outros.

Ao contrário dos personagens das novelas e contos citados, o "passageiro" não pode viver uma alternativa, mas também não estava à beira da morte; em seu caso, a morte foi simulada. Sua decisão de mudança foi repentina e dependeu do surgimento de uma oportunidade, que os demais não tiveram. À beira da morte, ao que parece, só pôde esperar por ela, no deserto, na cama, sem adoecimento. A doença que mata lentamente pode trazer o pensamento, as lembranças do que foi e as possibilidades de ser diferente; a morte repentina, possível, mas não certa, põe a dúvida na possibilidade de continuidade. O título do filme já traz a passagem como personagem, uma passagem que se encontra no sempre igual do deserto, no qual há muita dificuldade de vida fértil. A profissão de repórter, associada à rápida morte das notícias que transmite, reporta às marcas fugidias próprias às vivências apontadas por Baudelaire na capital do século XIX, que não fixavam lugar, sendo rapidamente substituídas por outras: a tentativa de Baudelaire superar as vivências com sua arte (BENJAMIN, 1989) novamente fracassou; no filme, descartáveis não são somente as vivências - as experiências empobrecidas -, mas a própria vida.

O repórter, agora traficante de armas, afirma que alguns hábitos, como fumar, não são passíveis de mudança, todo o resto, sim. A repetição presente no hábito nos prende no passado. Se no passado havia referências para mudanças, possibilidades não realizadas, mas existentes, no século XX não há mais referências que a poesia de Baudelaire ou a memória involuntária, descrita por Proust, ou a análise do inconsciente, como descrito pela Psicanálise, possam reencontrar. Não há objeto perdido, porque nada deve deixar marcas. A pretensão da vivência, que Baudelaire tentava superar, segundo Benjamin (1989), já indicava que não deveria haver vestígios da vida vivida, mas esses, no entanto, eram encontrados pelas novas técnicas de encontrar o assassino na multidão (daguerreotipo, aperfeiçoamento da impressão digital, numeração das moradias, alargamento das avenidas) e pelas técnicas da Psicanálise de encontrar o que era proibido pela moral vigente. No século XX, o declínio do narrador e a perda da aura dos objetos artísticos obrigam novas formas de contar o que não cabe nas palavras. Assim, Joyce (1998) deve recorrer a novas formas de linguagem para contar as consequências da dor de um filho perdido, entre elas as dificuldades amorosas com a mulher; Beckett (2005) reduz as palavras em um mundo sem saída; Kafka (1979) mostra o absurdo de um mundo no qual a racionalidade se encontra separada da razão. A narração não é mais possível como outrora (ADORNO, 2003).

Antonioni expressa bem, em sua obra, as dificuldades de se ater ao real, que parece ter perdido sua substância: o mercador de armas que não queria mais ser jornalista é assassinado como traficante, reconhecido pela nova companheira, não reconhecido pelo seu passado. A arquiteta que torna o mundo habitável permite ao novo morador o ingresso em sua vida; a esposa, amante de outro, desconhece que um dia o habitou.

Horkheimer e Adorno (1985) defendem que o enlouquecimento é devido à incapacidade de se alterar os pontos fixos de vista: "o verdadeiro tresloucar é a incapacidade de se desloucar." No presente, não há mais pontos fixos, tudo se altera; não há mais a diferença na identidade e, por isso mesmo, todos são aparências do que poderiam ser em um mundo efetivamente livre e justo, portanto humano. Pode-se perguntar se hoje o enlouquecimento não é também a impossibilidade em algo se fixar e poder com ele se identificar e ter experiências. Se o mesmo e o diferente compõem a identidade, um eu, sem o "eu que acompanha todas 
minhas representações", não pode ser o suporte para tantos deslocamentos. A fixação de objetos não deveria implicar aprisionamento, e, sim, base para novos deslocamentos e fixações, isto é, paixões, que podem idealizar o objeto, como mencionado antes, mas contêm o encanto do sujeito que busca por sua liberdade ao se diferenciar do objeto que idealiza, ao perceber que não é o que deseja que fosse, o que liberta o objeto, mas também a si próprio, pois não deveríamos também ser o que os outros desejam de nós.

Se como defendido no início deste texto, a subjetividade é tanto mais objetiva quanto mais pode expressar-se pela cultura, a diversidade experimentada tem na cultura a possibilidade de identificação, da nomeação do que é estranho e ao mesmo tempo familiar. Com a nomeação permitida pela cultura, o diverso não precisa ficar de fora. Não há formação sem a incorporação da cultura, que permite sermos os mesmos e ao mesmo tempo diversos outros; outros que a natureza comporta e que a cultura deveria possibilitar expressar. Se a cultura é natureza humana, nenhum dos dois polos - natureza e cultura - deveria ser abandonado, e os "eus" passíveis de identificação não precisariam implicar no fim da vida.

\section{REFERÊNCIAS}

ADORNO, Theodor W. Minima moralia: reflexões a partir da vida danificada. São Paulo: Ática, 1992.

. La posición del narrador en la novela contemporánea. In: . Notas sobre Literatura. Tradução de Alfredo Brotons Muñoz. Madri: Akal, 2003. p. 42-48.

Educação e emancipação. Tradução de W. L. Maar. Rio de Janeiro: Paz e Terra, 1995.

Sobre la relación entre Sociologia y Psicología. In: . Escritos Sociológicos I (Obra completa). Madrid: Ediciones Akal, 2004a. p. 39-78.

. Teoría de la pseudocultura. In: Akal, 2004 b. p. 86-113.

. Escritos Sociologicos I (Obra completa, Vol. 8). Madri: Ediciones

BAUDELAIRE, Charles. As flores do mal: edição bilingue. Tradução e notas de Fernando Pinto do Amaral. 4. ed. Lisboa: Assírio \& Alvim, 1998.

BECKETT, Samuel. Esperando Godot. Tradução e prefácio de Fábio de Souza Andrade. São Paulo: Cosac \& Naify, 2005.

BENJAMIN, Walter. Sobre alguns temas em Baudelaire. In: capitalismo. São Paulo: Brasiliense, 1989. p. 103-149.

. Charles Baudelaire: um lírico no auge do

DOSTOIEVSKI, Fiodor. Crime e castigo. Tradução de Paulo Bezerra. São Paulo: Ed. 34, 2001.

FREUD, Sigmund. O ego e o id. In:

. Pequena coleção das obras de Freud. Rio de Janeiro: Imago, 1975.

. El malestar en la cultura. In: BRAUSTEIN, N. A. (Org.). A medio siglo de El malestar en la cultura de Sigmund Freud. Tradução de J. L. Etcheverry. Ciudad de México: Siglo Veintiuno, 1986. p. 22-116.

. Psicología de las masas y análisis del yo. In:

verry. Buenos Aires: Amorrortu Editores, 1993. p. 63-136.

. Obras completas (Vol. 18). Tradução de J. L. Etche-

HEGEL, Georg Wilhelm Friedrich. Fenomenologia do Espírito (Parte 1). Petrópolis, RJ: Vozes, 1988.

HORKHEIMER, Max; ADORNO, Theodor W. Temas básicos de Sociologia. São Paulo: Cultrix, 1973. Zahar, 1985.

Dialética do esclarecimento: fragmentos filosóficos. Tradução de G. A. de Almeida. Rio de Janeiro: Jorge

JOYCE, James. Ulisses. Tradução de Antônio Houaiss. Rio de Janeiro: Civilização Brasileira, 1998.

KAFKA, Franz. A metamorfose e Um artista da fome. Tradução de Torrieri Guimarães. Rio de Janeiro: Ediouro, 1998.

O processo. Tradução de Torrieri Guimarães. São Paulo: Abril Cultural, 1979. 
MARX, Karl. Manuscritos econômicos-filosóficos. In: textos escolhidos. São Paulo: Abril Cultural, 1978. p. 7-48.

Manuscritos Econômicos-Filosóficos e outros

PASSAGEIRO: profissão repórter. Direção: Michelangelo Antonioni. Produção: Carlo Ponti. Intérpretes: Jack Nicholson; Maria Schneider; e outros. Roteiro: Michelangelo Antonioni e Mark Peploe. Rio de Janeiro: Warner Brothers, 1990. 1 videocassete (119 min).

PROUST, Marcel. No caminho de Swann. 2. ed. Porto Alegre: Globo, 1992.

Os prazeres e os dias. São Paulo: Códex, 2003.

TOLSTÓI, Leon. A felicidade conjugal. In: . Três novelas. Tradução de Boris Schnaiderman. São Paulo: Boa Leitura, 1959a. p. 15-120.

. A morte de Ivã Ilitch. In: . Três novelas. Tradução de Boris Schnaiderman. São Paulo: Boa Leitura, 1959b. p. 123-198.

O senhor e o servo. In:

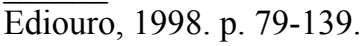
A morte de Ivan Ilitch - seguido de Senhores e Servos. Rio de Janeiro:

Recebido: $15 / 09 / 2017$

Aprovado: 15/10/2017 